\title{
EFFECT OF ORGANIC AND INORGANIC FERTILIZATION ON VEGETATIVE GROWTH AND VOLATILE OIL OF MARJORAM (Majorana hortensis L.) PLANT. Hamza, M. A. M. ${ }^{*}$ and E. S. E. Abd-Elhady** \\ * Horticulture Dept., Fac. Agric., Al Azhar University, Cairo, Egypt. ** Soils and Water Dept., Fac. Agric., Al- Azhar Univ., Cairo, Egypt.
}

\begin{abstract}
A field experiment was carried out during 2009/2010 season to evaluate organic and inorganic fertilization effects on vegetative growth, nutrient uptake and volatile oil of marjoram (Majorana hortensis L.) plant. The organic fertilization (sheep manure) was added a month before cultivation. Sheep manure at the rate of 20 $M^{3}$ fed ${ }^{1}$.

Six treatments were conducted; namely

1- Inorganic fertilization (100\%, recommended doze)

2- Organic fertilization (100\%)

3- Inorganic fertilization $75 \%$ + organic fertilization $25 \%$

4- Organic fertilization $75 \%+$ Inorganic fertilization $25 \%$

5 - Inorganic fertilization $50 \%$ + organic fertilization $50 \%$

6- The control treatment

Two cuts were harvested, the first one being after four months of planting (July month ) and the second one after seven months of planting (August month).

The results could be summarized as follows:

-The highest significant values of plant height and shoot number plant ${ }^{-1}$ in both $1^{\text {st }}$ and $2^{\text {st }}$ cuts as a result of increasing application organic fertilization treatments as compared with the control. Also data showed that, similar results in fresh and dry weight with $1^{\text {st }}$ and $2^{\text {st }}$ cuts as a result of increasing application organic fertilization treatments as compared with the control, on the other hand dry matter percentage, the highest significant values in both $1^{\text {st }}$ and $2^{\text {nd }}$ cuts as a result of increasing application organic fertilization treatments as compared with the control.

-The values of NPK increased as a result of increasing application organic fertilization treatments as compared with the control. On the other hand, the values of $\mathrm{Fe}, \mathrm{Zn}$, $\mathrm{Mn}$ and $\mathrm{Cu}$ decreased as a result of increasing application of organic fertilization treatments as compared with the control.

- The values of volatile oil percentage in herb in $1^{\text {st }}$ and $2^{\text {nd }}$ cuts were recorded with organic fertilization treatments.

-Terpinene-4-ol was the main component of volatile oil ,the highest percentages were recorded with organic fertilization treatments as compared with the control. This research is trying to reduce the mineral fertilizer application for their dangerous on general health and highly cost of these fertilizer, with improving production of important crops.
\end{abstract}

Keywords: Organic, inorganic, fertilization, volatile oil, marjoram (Majorana hortensis L.) plant

\section{INTRODUTION}

Marjoram, (Majorana hortensis L.) is a hardy perennial and herbaceous plant which grows in many areas of Egypt and eastern Mediterranean countries. Commercial M. hortensis L. oil (sweet marjoram) is used as a spice and condiment. Volatile oil produced by this plant is 
antispasmodic, digestive, bitter tonic, expectorant, diuretic, antidiabetic, antimicrobial, and antioxidant. In addition it is used in many industries. It is cultivated as culinary herb and as garden plants, Sivropoulou et al. (1996). Some properties like antimicrobial, antioxidant and antimutagenic activities have been attributed to the essential oil from Marjoram,( Dapkevicius et al. 1998).

Garg and Bahl (2008) reported that, organic materials are known to increase $P$ availability and enhance efficient use of applied $P$ fertilizer. Manure can also improves soil fertility, increase water-holding capacity, decline wind and water erosion, improves aeration, and promotes beneficial organisms. Johnson and Eckert,( 1995) reported that there are two principle objectives in applying animal manure to land: 1) to ensure the maximum utilization of the manure nutrients by crops and 2) to minimize water pollution hazard,. And also, manure plots showed higher dry matter production, species wealth, percentage cover, and drastic changes in botanical composition than that of non-manure plots. The principle objective of the present research was to identify manure management systems which minimize environmental pollution and result in good agronomic rangeland yields, (Mugerwa et al. 2008). The objective of this study was to evaluate the effect of organic and inorganic fertilization on vegetative growth, nutrient uptake and volatile oil of marjoram (Majorana hortensis L.) plant.

\section{MATERIALS AND METHODS}

The current investigation aims at evaluating fertilization effects on vegetative growth, nutrient uptake and volatile oil of marjoram ( $M$. hortensis )plant . A Field experiment was set up at Soil and Water department Farm, Faculty of Agriculture, Al - Azhar university, Nasr City , Cairo, Egypt.

\section{Plant materials.}

Plantlets of marjoram ( $M$. hortensis) were obtained from private nursery at Al- Kanatier Alkhairyia region grown in plastic pot $(8 \mathrm{~cm}), 10-15 \mathrm{~cm}$ of shoot length and 4-6 leaves .plantlets cultured in experimental area in $25^{\text {th }}$ March 2009

\section{The experimental soil}

The soil is sandy loam $(54.72 \%$ coarse sand, $21.33 \%$ fine sand, $11.13 \%$ silt and $12.82 \%$ clay), containing $0.89 \%$ organic matter, its soil bulk and particle densities are 1.32 and $2.62 \mathrm{~kg} \mathrm{~m}^{-3}$, respectively and its total porosity was $49.61 \%$. The experiment was conducted in a randomized complete block design with three replicates.

The experimental area was divided into equal size plots : the plot area was $1.5 \times 3.0$ meter, containing three ridges $50 \mathrm{~cm}$ apart, every ridge was 3 meters long containing 10 plants at $30 \mathrm{~cm}$ in between .

\section{Soil sampling and analyses}

The soil sample $(0-30 \mathrm{~cm}$ depth), was air dried and then ground to pass through a $2 \mathrm{~mm}$ sieve. Some physical and chemical analysis were carried out according to the standard methods undertaken by Black et al., (1965) and Page et al., (1982), the results are shown in Table 1. Also, 
available $\mathrm{Fe}, \mathrm{Mn}, \mathrm{Zn}$, and $\mathrm{Cu}$ were determined in the experiment of soil using ammonium bicarbonate-DTPA extractable according to Soltanpour and Schwab (1977) and their contents in the obtained extract were measured by Atomic Absorption spectrophotometer.

Table 1: Physical and chemical analyses of soil .

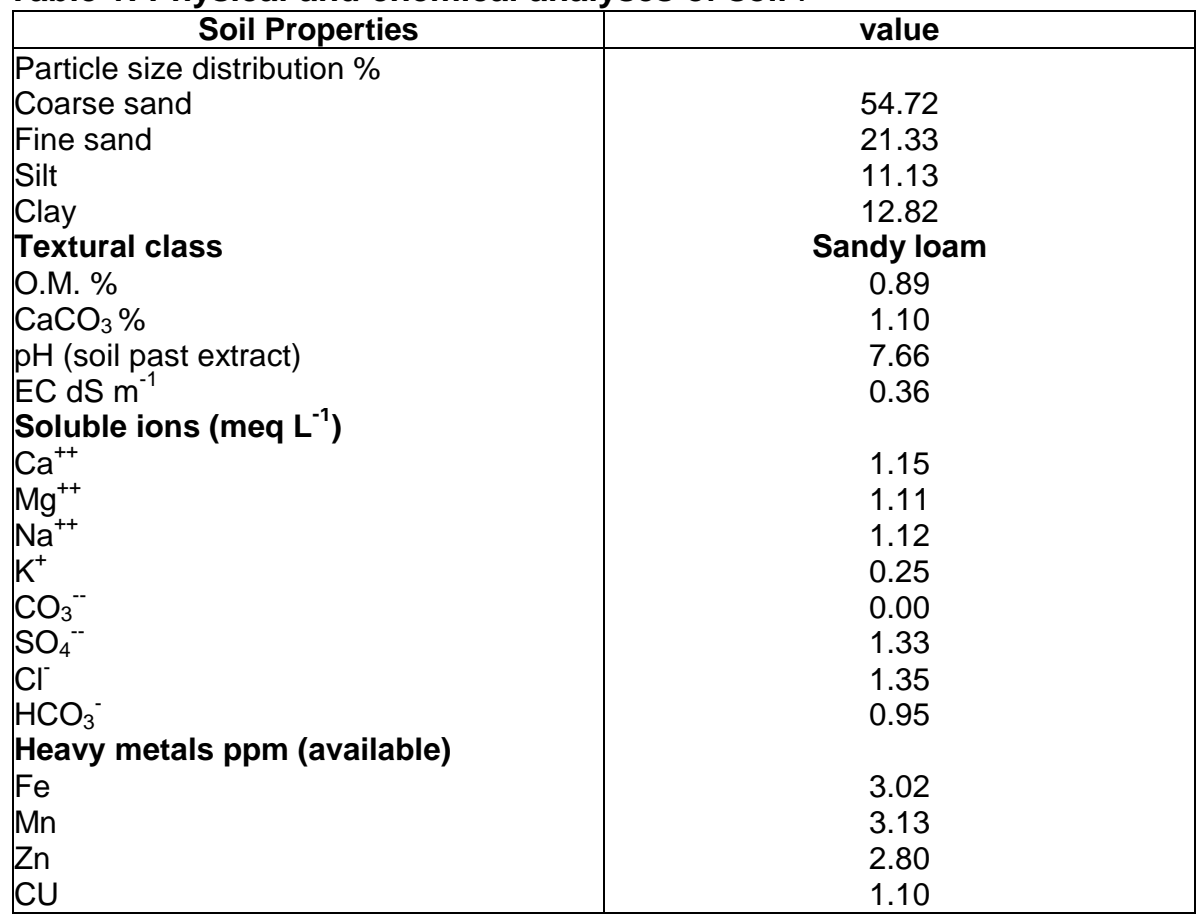

The experimental treatments.

Both the inorganic and organic fertilization rates were added according to the recommendation of the Ministry of agriculture. The organic fertilization (sheep manure) was added a month before cultivation at the rate of $20 \mathrm{M}^{3} \mathrm{fed}^{-1}$. The inorganic fertilization was added as ammonium sulfate and $\mathrm{K}$-sulfate at the rates of $300 \mathrm{and} 150 \mathrm{Kg} \mathrm{fed}^{-1}$, respectively. Fertilizer rats were splitted into two equal doses. The first addition was carried out 30days after transplanting, the second addition was performed after two weeks from the first cut (4.5months after transplanting, respectively).

Chemical analyses of organic fertilizer used in this experiment (Table 2) was carried out according to Black et al. (1965). The experimental treatments were as follow :

1- Inorganic fertilization (100\%, recommended doze)

2- Organic fertilization ( $100 \%$ )

3- Inorganic fertilization $75 \%$ + organic fertilization $25 \%$

4- Organic fertilization $75 \%+$ Inorganic fertilization $25 \%$

5- Inorganic fertilization $50 \%$ + organic fertilization $50 \%$

6- The control treatment 
Hamza, M. A. M. and E. S. E. Abd-Elhady

Table 2: Chemical analysis of sheep manure.

\begin{tabular}{|c|c|c|c|c|c|}
\hline $\begin{array}{c}\text { O.M. } \\
\%\end{array}$ & $\begin{array}{c}\mathbf{N} \\
\%\end{array}$ & $\begin{array}{c}\mathbf{K}_{2} \mathbf{O} \\
\%\end{array}$ & $\begin{array}{c}\mathbf{P}_{2} \mathbf{O}_{5} \\
\%\end{array}$ & $\mathbf{C} / \mathbf{N}$ ratio & $\begin{array}{c}\text { O.C. } \\
\%\end{array}$ \\
\hline 33.15 & 1.7 & 2.3 & 3.2 & 11.5 & 19.5 \\
\hline
\end{tabular}

\section{Measurement and Determinations:}

Two cuts were harvested, the first one being after four months of planting (July, 2009) and the second one after seven months of planting (August, 2009). The, studied vegetative parameters are:

1- Plant height $\mathrm{cm}_{\text {plant }}{ }^{-1}$

2- Shoot number plant ${ }^{-1}$

3- Fresh weight g. plant $^{-1}$, recorded after each cut.

4- Dry weight g. plant ${ }^{-1}$, dry weight of herb was recorded after air dried in shade room.

5- Dry matter percentage $=$ dry weight $/$ fresh weight $\times 100$. Dry matter production was calculated through the values of green production and dry weight percentage.

At the end of the experiment the harvested plants were digested to determine NPK and micronutrients; $\mathrm{Fe}, \mathrm{Mn}, \mathrm{Zn}$ and $\mathrm{Cu}$ according to Page et al. (1982). .

\section{Volatile oil extraction}

Marjoram Herb was extracted by steam distillation for 3-4 hour, according to the method described in British pharmacopoeia (1963). Gas Liquid Chromatography (GLC) method was used for the analyses of the essential oils.

The statistical analysis: All experiments were conducted under complete randomized design (CRD) with three replications and 9 plants for each replicate (Snedecor and Cochran, 1972) and the means were compared using L.S.D. test.

\section{RESULTS AND DISCUSSION}

\section{Effect of fertilization treatments on vegetative parameters of marjoram (Majorana hortensis L.) plant : \\ Plant height}

Data of Table 3 and Fig. 1 show that, the tallest significant values of plant height $\mathrm{cm}_{\text {plant }}{ }^{-1}$ were recorded with (100 inorganic , 100 organic, $75 \%$ inorganic $+25 \%$ organic and $50 \%$ inorganic $+50 \%$ organic, fertilization ) as $\left(70.3,67.0,70.0\right.$ and $69.6 \mathrm{~cm}$ plant ${ }^{-1}$, respectively) in $1^{\text {st }}$ cut . While, in $2^{\text {nd }}$ cut the best significant values were $\left(65.0,63.3\right.$ and $68.3 \mathrm{~cm}^{-1}$ plant $^{-1}$ respectively) recorded under (100\% organic, $75 \%$ inorganic $+25 \%$ organic and $75 \%$ organic $+25 \%$ inorganic fertilization). On the other hand, the lowest significant values of plant height $\mathrm{cm}$ plant ${ }^{-1}$ was recorded under control treatment in both $1^{\text {st }}$ and $2^{\text {nd }}$ cuts as (40.6 and $46.3 \mathrm{~cm}_{\text {plant }}{ }^{-1}$, respectively). Also data showed that, plant height $\mathrm{cm} /$ plant decreased under $100 \%$ inorganic in $2^{\text {nd }}$ cut $(55.0$ $\mathrm{cm}$ plant $\left.{ }^{-1}\right)$ comparing with $1^{\text {st }}$ cut $\left(70.3 \mathrm{~cm}_{\text {plant }}{ }^{-1}\right)$, also the same trend recorded with $75 \%$ inorganic $+25 \%$ organic were $\left(70.0 \mathrm{~cm}_{\text {plant }}{ }^{-1}\right.$ with $1^{\text {st }}$ cut) and $\left(63.3 \mathrm{~cm} /\right.$ plant, with $2^{\text {nd }}$ cut). 
Table 3: Effect of fertilization on vegetative parameters oil of marjoram (Majorana hortensis L.) plant.

\begin{tabular}{|c|c|c|c|c|c|c|c|c|c|c|}
\hline \multirow[b]{3}{*}{ Fertilization Treatments } & \multicolumn{10}{|c|}{ Vegetative parameter } \\
\hline & \multicolumn{5}{|c|}{$1^{\text {st }}$ cut } & \multicolumn{5}{|c|}{$2^{\text {nad }}$ cut } \\
\hline & 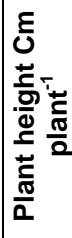 & 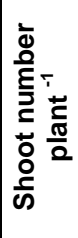 & 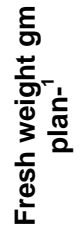 & 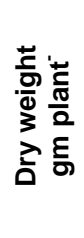 & 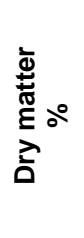 & 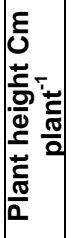 & 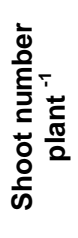 & 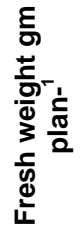 & 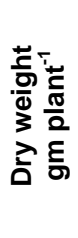 & 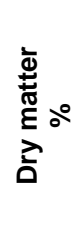 \\
\hline $100 \%$ inorganic f. & 70.3 & 16.3 & 322 & 104 & 32.29 & 55.0 & 9.6 & 161.3 & 43.5 & 26.96 \\
\hline $100 \%$ organic $f$. & 67.0 & 13.0 & 202.6 & 61 & 30.10 & 65.0 & 10.1 & 149.3 & 41.8 & 27.99 \\
\hline $75 \%$ inorganic+25\%organic & 70.0 & 16.0 & 337 & 102 & 30.26 & 63.3 & 10.5 & 176.3 & 51.1 & 28.98 \\
\hline 75 organic $+25 \%$ inorganic $f$. & 60 & 12.9 & 229 & 64 & 27.9 & 68.3 & 12.7 & 149.3 & 44.7 & 29.93 \\
\hline $50 \%$ inorganic +50 organic $f$. & 69.6 & 13.0 & 207 & 48.3 & 23.10 & 61.0 & 9.3 & 170 & 47.6 & 28.0 \\
\hline Control & 40.6 & 8.66 & 48 & 13.46 & 27.6 & 46.3 & 7.3 & 91 & 16.2 & 25.0 \\
\hline L.S.D. at $5 \%$ & 6.5 & 3.8 & 72 & 9.2 & 3.62 & & & & & \\
\hline L.S.D. at $5 \%\left(11^{\mathrm{st}}\right.$ Cut $)$ & 9.01 & 2.23 & 53.1 & 13.2 & 4.21 & & & & & \\
\hline L.S.D. at $5 \%\left(2^{\text {nd }} \mathrm{Cut}\right)$ & & & & & & 5.84 & 1.6 & 35.3 & 5.4 & 2.55 \\
\hline
\end{tabular}

It may be caused by solving inorganic fertilization in soil with water irrigation. Concerning, the effect of organic fertilization, the best significant results in both $1^{\text {st }}$ and $2^{\text {nd }}$ cuts were recorded with (100\% organic fertilization) it were $\left(67.0\right.$ and $65.0 \mathrm{~cm}$ plant $^{-1}$, respectively.

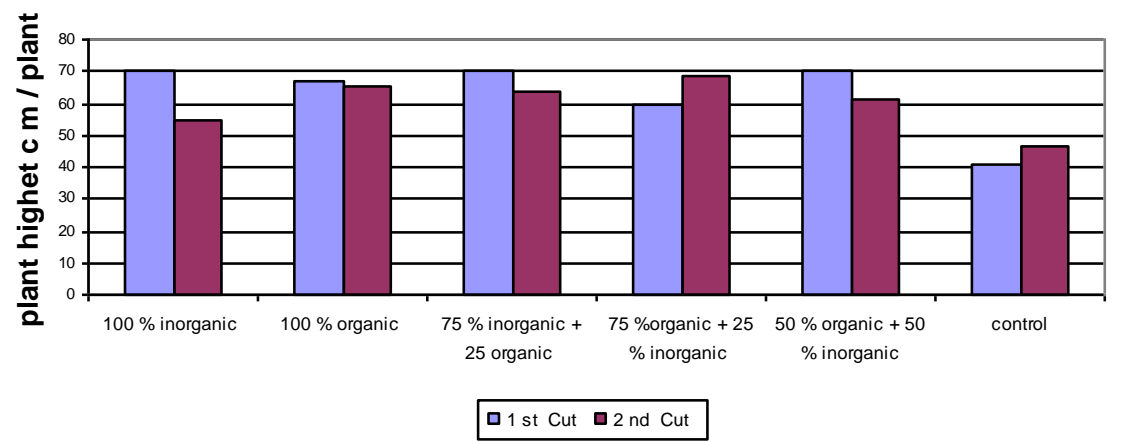

Fig.(1): Effect of fertilization on plant height $\mathrm{cm}_{\text {plant }}{ }^{-1}$

\section{Shoot number plant ${ }^{-1}$}

The biggest significant values of shoot number plant ${ }^{-1}$ recorded in $1^{\text {st }}$ cut with ( $100 \%$ inorganic fertilization) and ( $75 \%$ inorganic fertilization +25 organic fertilization) were (16.3 and 16.0 / plant ). While in the $2^{\text {nd }}$ cut with $(75$ $\%$ organic $+25 \%$ inorganic fertilization ) were (12.70 shoot number plant $\left.{ }^{-1}\right)$. On the other hand, the highest significant value of shoot number/plant in both two cuts recorded with $75 \%$ organic fertilization $+25 \%$ inorganic fertilization were (12.9 and 12.7 shoot number plant $\left.{ }^{-1}\right)$ in $1^{\text {st }}$ and $2^{\text {nd }}$ cuts, respectively. Concerning, the lowest significant values were recorded with control treatment ( 8.66 and 7.30 shoot number plant $\left.{ }^{-1}\right)$ in $1^{\text {st }}$ and $2^{\text {nd }}$ cuts, 
respectively. Our results were in agreement with, Hanife, et al (2010) who reported that, the effects of manure applications on ratios of legume, grass, and other plants in the botanical composition were found to be significant.

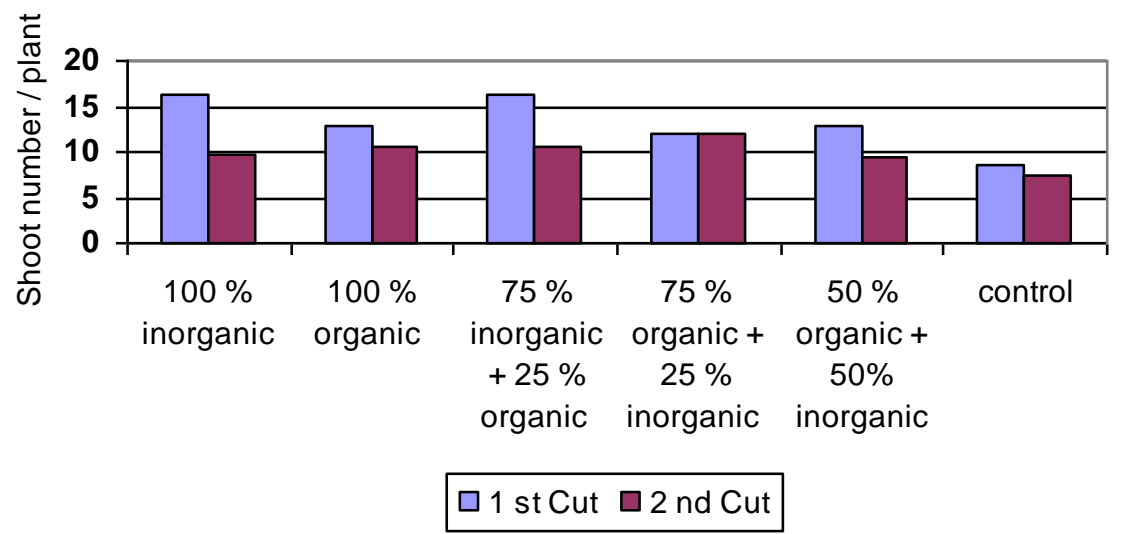

Fig.(2): Effect of fertilization on shoot number plant ${ }^{-1}$

Fresh weight (g. plant $^{-1}$ )

Herb of marjoram plants were positively responded to increased levels of either inorganic and organic Inorganic fertilization (100\%) and $75 \%$ inorganic $+25 \%$ organic fertilization recorded the highest significant values of fresh weight $\mathrm{gm} /$ plant in $1^{\text {st }}$ cut as follow (322 and $337 \mathrm{~g}$. plant ${ }^{-1}$, respectively). While in $2^{\text {nd }}$ cut, Inorganic and organic fertilization treatments had no significant effect on fresh weight $\mathrm{gm} \mathrm{plan}^{-1} \mathrm{t}$, regardless the control treatment which was recorded the lowest significant value $\left(91 \mathrm{~g}\right.$. plant $\left.{ }^{-1}\right)$. The best result of fresh weight gm/plant recorded in $2^{\text {nd }}$ cut was recorded with 75 $\%$ inorganic $+25 \%$ organic fertilization $\left(176.3 \mathrm{~g}\right.$. plan $\left.^{-1} \mathrm{t}\right)$. On the other hand ,the biggest values of fresh weight g.plant ${ }^{-1}$ in two cuts were recorded with 75 \%inorganic $+25 \%$ organic fertilization (337g. plant ${ }^{-1}$ in $1^{\text {st }}$ cut and 176.3 g./plant in $2^{\text {nd }}$ cut). While the lowest values were recorded with control treatment (48 g.plant ${ }^{-1}$ in $1^{\text {st }}$ cut and $91 \mathrm{gm} \mathrm{plant}^{-1}$ in $2^{\text {nd }}$ cut) Fig. 3.

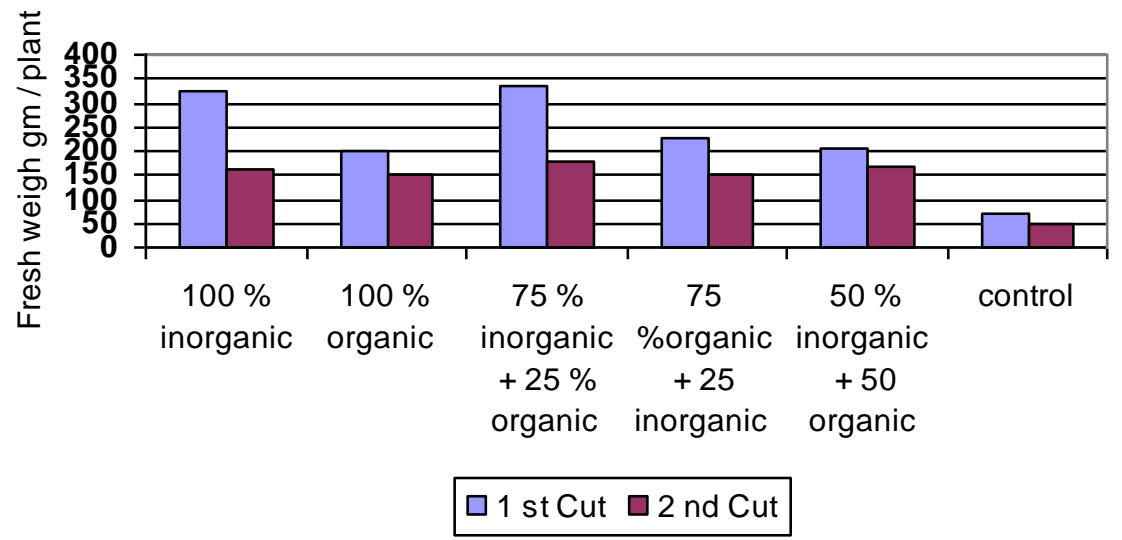

Fig.(3): Effect of fertilization on fresh weight (g. plant ${ }^{-1}$ ) 


\section{Dry weight (g. plant ${ }^{-1}$ )}

Dry weight values during $1^{\text {st }}$ cuts behaved similarly in the same trend shown by fresh weight of marjoram plant . $100 \%$ inorganic fertilization and 75 $\%$ inorganic $+25 \%$ organic fertilization were recorded the highest significant values of dry weight plant ${ }^{-1}$ (104 and 102 g. plan ${ }^{-1} t$, respectively in $1^{\text {st }}$ cut). While, in $2^{\text {nd }}$ cut , the best significant values of dry weight $\mathrm{gm} /$ plant recorded with( $75 \%$ inorganic $+25 \%$ organic fertilization ) and ( $50 \%$ inorganic +50 organic fertilization) were $\left(51.1\right.$ and $47.6 \mathrm{~g}$. plant $\left.{ }^{-1}\right)$. On the other hand, control treatment recorded in $1^{\text {st }}$ and $2^{\text {nd }}$ cuts the lowest significant values of dry weight gm plant ${ }^{-1}$ (13.46 and $16.2 \mathrm{~g}$. plant ${ }^{-1}$, respectively). Treating marjoram plants with sheep manure increased the formation of vegetative growth, this may be due to the increase of phosphorus mineralization with sheep manure and the increase in dry weight may be due to increase in fresh weight which was reflected as an increase in the plant height and the shoot number. These results in line with, Gewaily et al (2006) reported that, inoculation of marjoram plant with bio fertilizer and using organic residues enhanced the vegetative growth. At the same time, increases in nitrogen content in the soil as a result of nitrogen fixation may enhance the mineralization process, Dewidar (2007).

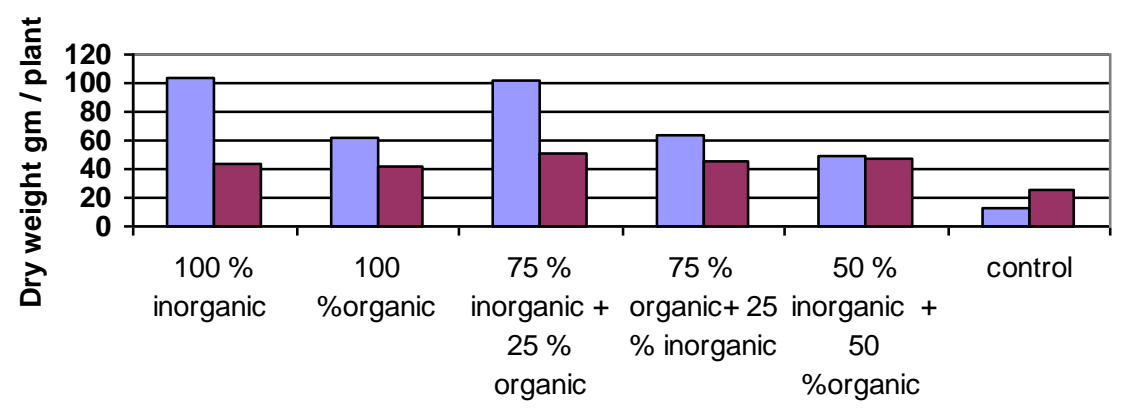

$\square 1$ st Cut $\square 2$ nd Cut

Fig.(4): Effect of fertilization on dry weight (g. plant $^{-1}$ )

\section{Dry matter percentages}

The highest significant values of Dry matter percentage were recorded with $100 \%$ inorganic, $100 \%$ organic and $75 \%$ inorganic $+25 \%$ organic fertilization, in $1^{\text {st }}$ cut were $(32.29,30.10$ and $30.26 \%$ respectively). While, in $2^{\text {nd }}$ cut, $100 \%$ organic , $75 \%$ inorganic $+25 \%$ organic, $75 \%$ organic $+25 \%$ inorganic and $50 \%$ inorganic $+50 \%$ organic fertilization treatments recorded the best significant results (27.99, 28.98,29.93 and 28.0 $\%)$. On the other hand, the lowest significant values of dry matter percentage in $1^{\text {st }}$ cut were recorded with $50 \%$ inorganic $+50 \%$ organic fertilization $(23.1$ $\%)$. while in $2^{\text {nd }}$ cut, $100 \%$ inorganic fertilization and control treatments recorded the lowest significant values $(26.96 \%$ and $25.0 \%$, respectively). In general, the results of dry matter in both $1^{\text {st }}$ and $2^{\text {nd }}$ cuts showed that, the highest significant values were recorded with $75 \%$ inorganic $25 \%$ organic fertilization $\left(30.2 \%\right.$ in $1^{\text {st }}$ and $28.98 \% 2^{\text {nd }}$ cuts, respectively), while the 
lowest significant values were recorded with control treatment. Our results were in agreement with, Hanife, et al. (2010) who reported that, total dry matter production was improved by the application of manure, and the application of sheep manure on rangelands will be able to increase dry matter yield, Fig 5.

Effect of fertilization treatment, on values of macronutrients content and uptake in plant.

Concerning the effect of fertilization treatments application NPK content and uptake by (Majorana hortensis L.) plant, the data presented in Table 5 show that values of NPK content (\%) and uptake (mg/plant). Were affected due to the application of fertilization treatments as compared with the untreated control.

The highest values of NPK content \% and uptake (mg/plant) obtained with $100 \%$ organic and $75 \%$ organic $+25 \%$ inorganic and $50 \%$ organic $+50 \%$ inorganic treatments, in both $1^{\text {st }}$ and $2^{\text {nd }}$ cuts as compared with the lowest values with the untreated control. These increases in NPK content $\%$ and uptake (mg/plant) by (Majorana hortensis L.) plant with organic fertilization might be due to the role of organic fertilization in improving of soil fertility and increasing the availability of these macronutrients. In this concern, Abd-Elhady 2007, who found that application of organic matter, and clay minerals played an important role in chemical behavior of macronutrients in soil and plant. These are in agreement with those of Zai et al., 2008, who stated that the compost of pea residue with chicken manure and chicken manure plus rapeseed residue enriched soil with NPK and other nutrients, and increased nutrient accumulation in plant.

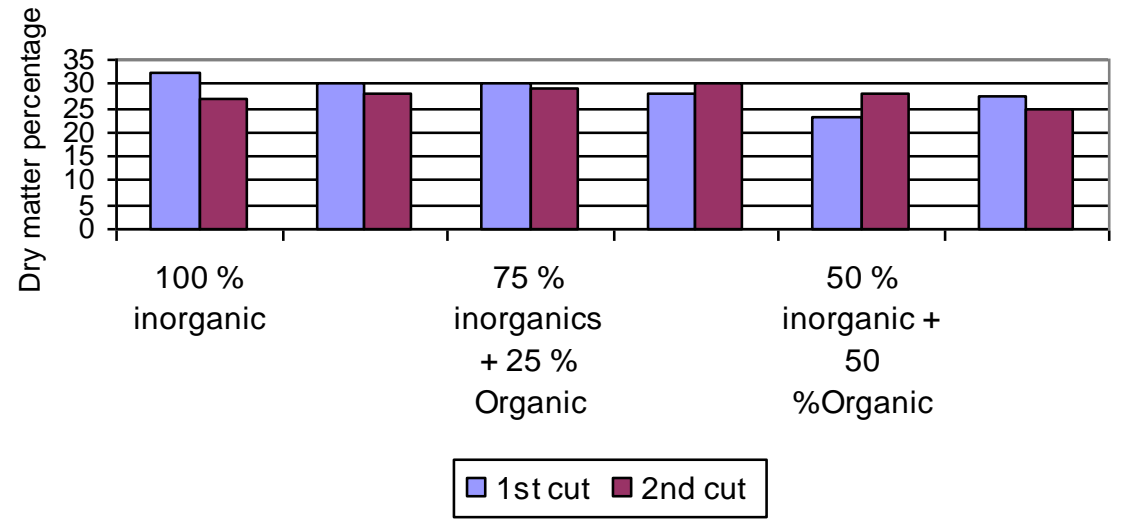

Fig.(5): Effect of fertilization on dry matter percentage

\section{Effect of fertilization treatment on values of micronutrient content and uptake in plant.}

The data of micronutrients content and uptake by (Majorana hortensis L.) plants, the data presented in Table 4 show that the values of $\mathrm{Fe}, \mathrm{Zn}, \mathrm{Mn}$ and $\mathrm{Cu}$ content $\left(\mathrm{mgkg}^{-1}\right)$ and uptake $(\mu \mathrm{g} / \mathrm{plant})$ were affected due to the application of organic and inorganic fertilization as compared with the untreated control. 
J. Soil Sci. and Agric. Engineering, Mansoura Univ., Vol.1 (8),August, 2010

4 
The results showed that the available content $\left(\mathrm{mgkg}^{-1}\right)$ and uptake $(\mu \mathrm{g} / \mathrm{plant})$ amounts of $\mathrm{Fe}, \mathrm{Zn}, \mathrm{Mn}$ and $\mathrm{Cu}$ were reduced with increasing application of organic fertilization at 100 organic and $75 \%$ organic $+25 \%$ inorganic treatment as compared with untreated control. This pointed out the important role of application of organic fertilization, which reduced the solubility of heavy metals in soil and plant. These results are in agreement with those of Abd-Elhady (2007) who recorded that the application of organic fertilization were an important soil component in the adsorption of metals. Also, Herwijnen et al., (2007), suggested that metal immobilization and bioavailability are governed by the formation of complexes between metals and organic matter.

\section{Volatile oil percentage}

With respect to Volatile oil percentage, the highest two values of volatile oil percentage were recorded in $1^{\text {st }}$ cut with $75 \%$ organic $+25 \%$ inorganic fertilization (1.0\%) and $100 \%$ inorganic fertilization $(0.92 \%)$. While in $2^{\text {nd }}$ cut with $75 \%$ organic $+25 \%$ inorganic fertilization $(1.4 \%)$ and $75 \%$ inorganic $+25 \%$ organic fertilization (1.32\%). On the other hand, the lowest values of volatile oil percentage recorded with control treatment in both two cuts $(0.32 \%$ and $0.44 \%$, respectively). Also, previously data showed that, 75 $\%$ organic $+25 \%$ organic fertilization recorded the biggest values of volatile oil percentage in both $1^{\text {st }}$ and $2^{\text {nd }}$ cuts $(1.0 \%$ and $1.4 \%$, respectively). In general, oil yield was much higher for the $2^{\text {nd }}$ cut than that of the $1^{\text {st }}$ under organic fertilization treatment and induced relative increase by about 2-3 fold over the control at the $1^{\text {st }}$ and $2^{\text {nd }}$ cuts. Our results are in line with, ElGhandour et al. (2009) who stated that oil yield was higher in sheep manure amendment treatment from Table 4 and fig.6, It can be concluded that marjoram plants as medicinal plants significantly responded to organic fertilization which positively affected plants vegetative growth and the volatile oil yield.

Table 5: Effect of fertilization on volatile oil of marjoram (Majorana hortensis L.) plant.

\begin{tabular}{|l|c|c|}
\hline \multirow{2}{*}{ Fertilization Treatments } & \multicolumn{2}{|c|}{ Volatile oil \% } \\
\cline { 2 - 3 } & $\mathbf{1}^{\mathbf{s}}$ cut & $\mathbf{2}^{\text {nd }}$ Cut \\
\hline $100 \%$ inorganic fertilization & 0.92 & 0.96 \\
\hline 100 organic fertilization & 0.60 & 1.20 \\
\hline $75 \%$ inorganic $+25 \%$ organic fertilization & 0.56 & 1.32 \\
\hline 75 organic $+25 \%$ inorganic fertilization & 1.0 & 1.40 \\
\hline $50 \%$ inorganic +50 organic fertilization & 0.50 & 1.04 \\
\hline Control & 0.32 & 0.44 \\
\hline
\end{tabular}




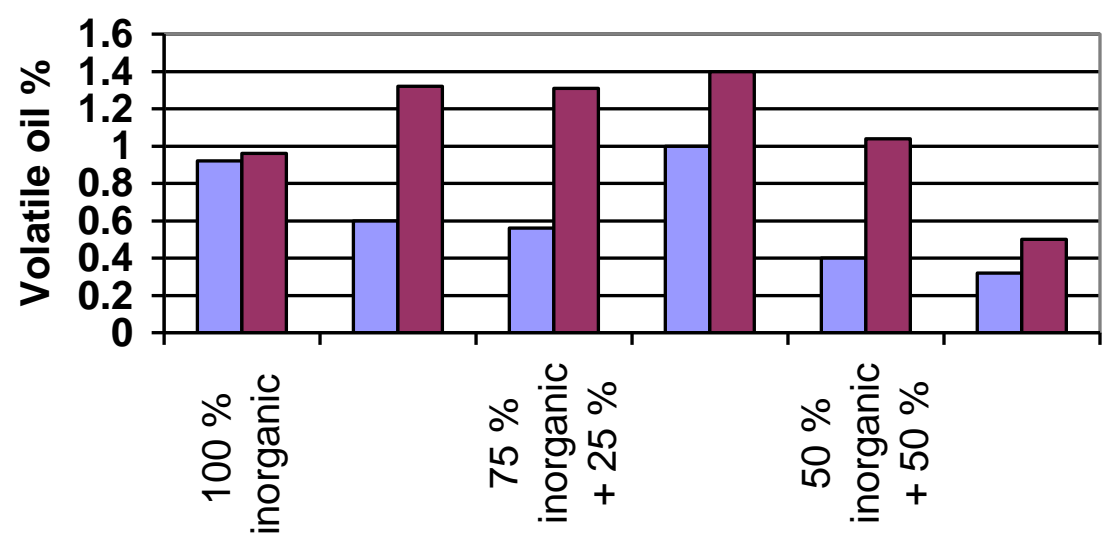

\section{$\square 1$ st Cut $\square 2$ nd Cut}

Fig.(6): Effect of fertilization on volatile percent

Data in Table 6 showed that, the main components of marjoram herb were Terpinene-4-ol, limonene , $\beta$-pinene and mercene. The highest percentage of Terpinene-4-ol was recorded with control, $75 \%$ organic $+25 \%$ inorganic and $100 \%$ inorganic fertilization in $2^{\text {nd }}$ cut $(39.5,38.2$ and $374 \%)$ while in $1^{\text {st }}$ cut the highest percentage $(35.96 \%)$ was recorded with $75 \%$ organic $+25 \%$ inorganic fertilization. In limonene percentage the highest percentage (17.6 and $15.5 \%$, with $1^{\text {st }}$ and $2^{\text {nd }}$ cuts respectively) were recorded with control treatment.

Table 6: Effect of fertilization on main components of Volatile oil of marjoram (Majorana hortensis L.) plant.

\begin{tabular}{|c|c|c|c|c|c|c|c|c|c|c|}
\hline \multirow[b]{2}{*}{ Fertilization Treatments } & Cuts & \multicolumn{9}{|c|}{ Volatile oil component } \\
\hline & \multirow[t]{7}{*}{$1^{\text {st }}$ cut } & 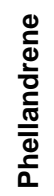 & 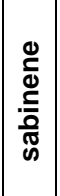 & 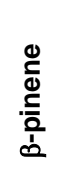 & 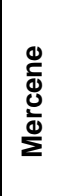 & 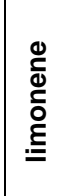 & 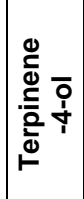 & 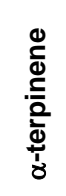 & 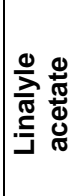 & $\mid \frac{\frac{9}{0}}{\frac{0}{0}}$ \\
\hline $100 \%$ inorganic $f$. & & 5.7 & 5.3 & 10.1 & 8.0 & 10.6 & 27.0 & 5.6 & 1.8 & 1.9 \\
\hline $100 \%$ organic $f$. & & 1.2 & 6.8 & 6.5 & 8.8 & 14.2 & 30.3 & 6.3 & 2.1 & 0.69 \\
\hline $75 \%$ inorganic $+25 \%$ organic f. & & 4.1 & 3.8 & 7.7 & 11.8 & 15.2 & 33.6 & 5.8 & 1.1 & 1.5 \\
\hline 75 organic $+25 \%$ inorganic f. & & 4.6 & 4.6 & 8.6 & 6.1 & 8.8 & 35.9 & 7.1 & 2.2 & 1.6 \\
\hline $50 \%$ inorganic +50 organic $f$. & & 3.4 & 5.1 & 11.1 & 8.0 & 8.9 & 32.5 & 4.8 & 1.4 & 0.65 \\
\hline Control & & 1.8 & 1.9 & 4.4 & 1.1 & 17.6 & 30.3 & 7.6 & 1.9 & 3.4 \\
\hline $100 \%$ inorganic f. & \multirow[t]{5}{*}{$2^{\text {nd }}$ cut } & 5.5 & 5.7 & 10.9 & 8.7 & 12.4 & 37.4 & 5.3 & 0.00 & 0.89 \\
\hline $100 \%$ organic $f$. & & 5.4 & 5.0 & 9.1 & 15.8 & 2.2 & 29.3 & 5.9 & 0.46 & 2.1 \\
\hline $75 \%$ inorganic $+25 \%$ organic $f$ & & 2.4 & 7.7 & 14.6 & 6.4 & 7.4 & 34.0 & 5.7 & 0.0 & 1.4 \\
\hline 75 organic $+25 \%$ inorganic f. & & 1.7 & 5.9 & 11.6 & 5.1 & 2.4 & 38.2 & 8.2 & 0.4 & 1.8 \\
\hline $50 \%$ inorganic + 50 organic f. & & 2.5 & 6.1 & 10.3 & 7.9 & 11.7 & 30.1 & 1.2 & 0.56 & 0.8 \\
\hline Control & & 1.2 & 2.4 & 7.5 & 6.2 & 15.5 & 39.5 & 7.0 & 0.33 & 0.79 \\
\hline
\end{tabular}


Concerning $\beta$-pinene, the best percentage were recorded with $75 \%$ inorganic $+25 \%$ organic and $75 \%$ organic $+25 \%$ inorganic (14.6 and 11.65 $\%)$ in $2^{\text {nd }}$ cut . While in mercene , $100 \%$ organic and $75 \%$ inorganic $+25 \%$ organic fertilization were recorded the best percentage in $2^{\text {nd }}$ and $1^{\text {st }}$ cuts, respectively it were (15.8 and $11.8 \%)$. In general, previous data show that, $2^{\text {nd }}$ cut gave the highest results compared with $1^{\text {st }}$ cut .

\section{REFERENCES}

Abd-Elhady E. S. (2007). Studies on soil contamination in some soils of Egypt. Ph. D. Thesis. Fac. of Agric. Al-Azhar Univ.

Beek and J.P.H. Linssen (1998) Antioxidant activity of extracts obtained by different isolation procedures from some aromatic herbs grown in Lithuania. J. Sci. Food Agric., 77: 140-146

Black, C. A., Evans, D. D., Ensminger, L. E., White, J. L. And Clark, F. E. (1965) "Methods of Soil Analysis" Amer. Soc. Agron. Inc., Pub, Madison,Wisc. USA

British Pharmacopoeia (1963). Determination of volatile oil in drugs. The Pharmaceutical press, London.

Dewidar, A. A. (2007). Post harvest studies on some aromatic plants. Ph.D. thesis Horticulture Dep. Fac. Of Agriculture. Kafr Elsheikh Univ. Egypt.

Dapkevicius, A.; R. Venskutonis; T.A. van Beek and T.A.Linssen (1998). Antioxidant activity of extracts obtained by different isolation procedures from some aromatic herbs grown in Lithuania. J. Sci. Food Agric., 77, 140146.

El-Ghandour, I.A .; M.D. Enayat ; G.M. Yehia; R.A. Arafa and A.M. Abou Seer ( 2009) Effect of biofertilizers and organic phosphorus amendments on growth and essential oil of marjoram (Majorana hortensis L.) Egypt. Acad. J. biolog. Sci., 1(1): 29-36

Herwijnen, R. V., Hutchings, T. R., Al-Tabbaa, A., Moffat, A. J. Johns, M. L.and Ouki, S. K. (2007). Remediation of metal contaminated soil with mineralamended composts. Environmental Pollution., 150 (3): 347- 354.

Garg, S. and G.S. Bahl (2008) Phosphorus availability to maize as influenced by organic manures and fertilizer $\mathrm{P}$ associated phosphatase activity in soils. Bioresour. Technol., 99: 5773-5777.

Gewaily, E. M.; F. I. El-Zamik; T. T. EL -Hadidy; H.I. Abd El-Fattah and S. H. Salem (2006). Efficiency of biofertilizers, organic and inorganic amendments application on growth and essential oil of marjoram (Majorana hortensis L.) plants grown in sandy and calcareous soils. Zagazig J. Agric. Res., 33: 205-230.

Hanife, M.; A. Ilknur; B. Ugur; O. Ozlem and A. Zeki (2010). The effects of sheep manure application time and rates on yield and botanical composition of secondary succession rangeland. African Journal of Biotechnology, 9(23): 3388-3395.

Johnson, J. and D. Eckert (1995). Best management practices: Lanapplication of animal manure. Ohio State University Extension Publication AGF-208-95

Mugerwa, S, Mpairwe D, Sabiiti EN, Mutetikka D, Kiwuwa GH, Zziwa E. and Peden D (2008). Effect of cattle manure and reseeding on pastureproductivity. CPWF Second International Forum on Water and Food, Addis Ababa, Ethiopia, November 10-14. 
Page, A. L., R. H. Miller and D. R. Keeny (1982). Methods of soil analysis. Part ח. Chemical and microbiological properties ( $2^{\text {rd }}$ ed.)

Amer. Soc. Agron. Monograph no. 9 Madison, Wisconsin, USA. Sivropoulou, A.; E. Papanicolaou; C. Nicolaou; S. Kokkin; T. Lanaras and M. Arsenakis (1996) Antimicrobial and cytotoxic activities of origanum essential oils. J. Agric. Food Chem., 44:1202-1205.

Snedecor, G .W. and W.G. Cochran (1972) Statistical methods 6 th Ed ; lowa state Univ. Press , Ames, Iwoa, U.S.A. P.953

Soltanpour, N. and Schwab, A. P. (1977). A new soil test for simultaneous extraction of macro and micronutrients in alkaline soils. Comm. Soil Sci. Plant Annal., 3: 195.

Zai, A. K. E., T. Horiuchi and T. Matsui (2008). Effects of compot and green manure of pea and their combinations with chicken manure and rapeseed oil residue on soil fertility and nutrient uptake in wheat - rice cropping system. African Journal of agricultural research, 3(9): $633-639$.

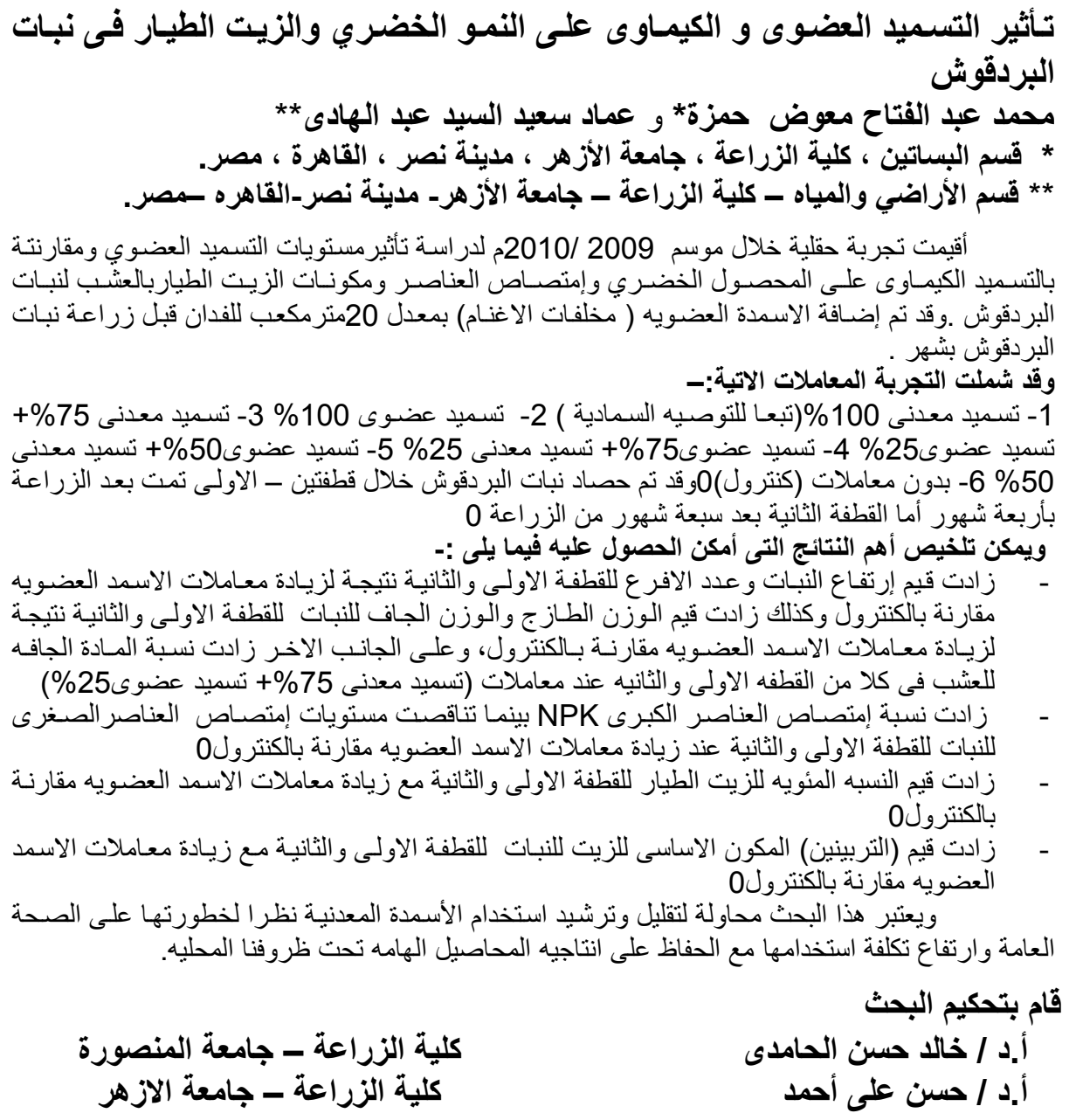


Table 4: Effect of fertilization treatment, on values of macro and micro nutrients content and uptake in plant.

\begin{tabular}{|c|c|c|c|c|c|c|c|c|c|c|c|c|c|c|}
\hline \multirow[b]{2}{*}{ Fertilization Treatments } & \multicolumn{2}{|c|}{$\mathbf{N}$} & \multicolumn{2}{|c|}{$\mathbf{P}$} & \multicolumn{2}{|l|}{$k$} & \multicolumn{2}{|c|}{$\begin{array}{l}\text { Cut } 1{ }^{1 /} \\
\mathrm{Fe}\end{array}$} & \multicolumn{2}{|c|}{$\mathrm{Mr}$} & \multicolumn{2}{|c|}{ Zn } & \multicolumn{2}{|r|}{$\mathrm{Cu}$} \\
\hline & 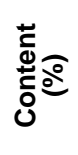 & 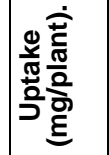 & 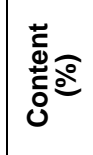 & 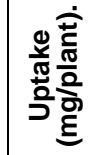 & 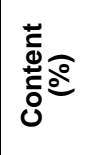 & 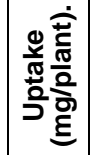 & 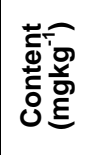 & 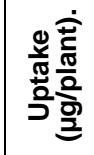 & 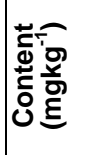 & 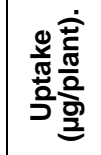 & 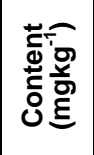 & 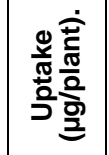 & 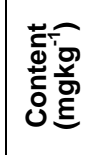 & 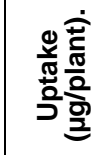 \\
\hline $100 \%$ inorganic $f$. & 0.99 & 10.29 & 0.302 & 3.14 & .041 & 0.42 & 10.61 & 1103.4 & 29.44 & 3061.7 & 67.20 & 3988.8 & 30.6 & 3182.4 \\
\hline $100 \%$ organic $f$. & 1.73 & 10.55 & 0.336 & 2.049 & 0.060 & 3.66 & 3.70 & 225.7 & 22.68 & 1383.4 & 56.97 & 3475.1 & 26.71 & 1629.3 \\
\hline $75 \%$ inorganic $+25 \%$ organic f. & 1.44 & 14.68 & 0.302 & 2.06 & 0.060 & 0.612 & 6.62 & 675.2 & 26.58 & 2711.1 & 48.81 & 4978.6 & 12.48 & 1272.9 \\
\hline 75 organic $+25 \%$ inorganic $f$. & 1.68 & 10.752 & 0.386 & 2.470 & 0.075 & 0.480 & 8.54 & 565.7 & 6.66 & 426.24 & 86.83 & 5557. & 19.34 & 1237.7 \\
\hline $50 \%$ inorganic +50 organic $f$. & 1.53 & 7.389 & 0.297 & 1.434 & 0.069 & 0.333 & 11.43 & 548.9 & 30.07 & 144.2 & 81.69 & 3923.5 & 22.45 & 1078.2 \\
\hline Control & 0.98 & 1.319 & 0.270 & 0.367 & 0.063 & 0.084 & 2.00 & 114.81 & 8.53 & 678.3 & 50.40 & 143.07 & 10.63 & 25.95 \\
\hline \multicolumn{15}{|c|}{ Cut 2} \\
\hline $100 \%$ inorganic $f$. & 1.82 & 0.873 & 0.427 & 1.85 & 0.072 & 0.313 & 15.15 & 441.5 & 32.35 & 1407.2 & 74.85 & 3255.9 & 25.76 & 1120.05 \\
\hline $100 \%$ organic $\mathrm{f}$. & 1.91 & 7.983 & 0.539 & 2.953 & 0.085 & 0.355 & 9.49 & 395.6 & 30.45 & 1272.8 & 81.05 & 3387.8 & 317.66 & 738.18 \\
\hline $75 \%$ inorganic $+25 \%$ organic f. & 2.09 & 10.679 & 0.610 & 3.117 & 0.080 & 0.408 & 13.82 & 659.2 & 28.32 & 1447.1 & 63.81 & 3260.6 & 19.39 & 990.8 \\
\hline 75 organic $+25 \%$ inorganic $f$. & 1.62 & 7.241 & 0.521 & 2.328 & 0.083 & 2.328 & 11.67 & 521.6 & 28.13 & 1257.4 & 81.05 & 3622 & 20.44 & 951.73 \\
\hline $50 \%$ inorganic +50 organic $f$. & 1.62 & 7.711 & 0.485 & 0.357 & 0.075 & 0.357 & 7.06 & 336.5 & 23.86 & 1135.7 & 91.24 & 4343.2 & 18.25 & 868.7 \\
\hline Control & 1.6 & 2.292 & 0.277 & 0.142 & 0.088 & 0.142 & 1.62 & 25.95 & 11.98 & 191.91 & 57.4 & 919.5 & 11.63 & 186.3 \\
\hline
\end{tabular}

